\title{
Utopian Desire in Percy Bysshe Shelley's Poetry
}

\author{
Parastoo Salavati \\ Department of Foreign Languages, Faculty of Foreign Languages, \\ Sanandaj Payam-E-Noor University, Sanandaj, Kurdistan, Iran. \\ E-mail: parastoo_salavati@yahoo.com
}

Doi:10.5901/ajis.2013.v2n8p267

\begin{abstract}
This study has considered the Utopian desire in Percy Bysshe Shelley's major poems. It describes Shelley's idealism and Utopian desire based on the creative power of love. Shelley's Utopia is an imaginary land in which love creates, while hatred brings about destruction. Shelley can be considered as the culmination of the Romantic Movement in English literature. He looks at nature primarily as a realm of overwhelming beauty and aesthetic pleasure. His works deal with the subjective world of ideals that is more real to him than the world of facts. He is a poet of idealism and love, a representative of hope and liberty, who desires to change the world to Eden before the fall of man. His idealism is based on the elimination of all sorts of tyranny and oppression to terminate a liberal and humane world. Since Shelley's Utopia is governed only by justice, love and beauty, good triumphs over evil when love dominates man's heart and society, because according to him, love is a harmonizing power that joins and supports the elements to bring about creation. Shelley's seclusion from the world of men and his dissatisfaction and failure in the actual life lead him to a higher world that is created by poetry and ruled by love and beauty, a Utopian Land that affords relief from what is unbearable in the social world and is much more beautiful and more perfect than the external world.
\end{abstract}

Keywords: Utopian desire, Percy Bysshe Shelley's poetry, Love, Idealism

\section{Introduction}

Percy Bysshe Shelley's views, like those of the first generation of Romantic poets, were shaped to some extent by the French Revolution and its consequences, emphasizing individual vision, lyricism, and idealism. Although the spirit of the French Revolution was still alive in radical and intellectual circles, Shelley and his radical contemporaries were far less familiar with its victory than with its defeat.

At that time, while the breaking up of the old stabilities and established order cultivated and craved an awareness of radical changes and reformation that were viewed as parallel with the age, the romantic poets were considered as the agents of hope and freedom and they were met with enthusiasm because their concept of the poet-rebel was related to idealism and freedom.

The French revolution, which had almost disillusioned the first generation of English Romantic poets, was already part of history for the younger generation. The poetry of Keats and Shelley loses almost entire touch with the national life and the historic traditions of England. Shelley and Byron were captivated less than Wordsworth by the beauty of nature; their imagination was captivated by the ideals of freedom, beauty and love rather than nature. We have natural elements in Shelley's poetry, but they are symbols for his emotional patterns.

While English Romantic poets of the first generation are considered as the prophets of nature, those of the second generation are the creators of beauty. They use their imagination and revolutionary ideas to break down the limits and build a visionary world ruled by man's spirit, love and beauty, which cannot be differentiated by Shelley.

Shelley as a member of ruling class, was a pioneer of political and spiritual rebellion. He was considered as a prophet of social and psychological revolution and his political thought inspired some other poets. Shelley is a revolutionary and radical poet whose literary work is a synthesis of a great reformist, visionary and idealist.

As a poet, Shelley is one of the most subjective of writers, but he contributes a new quality to English literature, the quality of ideality and freedom, that is not found in other Romantic poets. No other Romantic poet shares the prophetic fire which burns in Shelley's verse. In none of Shelley's greatest contemporaries is the lyrical faculty so paramount; and whether we consider his minor songs, his odes, or his more complicated choral dramas, one has to acknowledge that he is the loftiest and the most spontaneous lyrical poet of the nineteenth century. Not only has he written the best idealistic lyrics, but also the most idealistic tragedy of his century. 
Most of Shelley's poems reveal his Utopian desire, a philosophic idealism by which he tries to create a Utopia. Shelley's idealism is a combination of belief in the power of human love and reason and in the perfectibility and ultimate progress of man. Love becomes effective when hatred is ended. Shelley is a firm believer in the power of love and makes it the principal theme of his poetry. Love is the root and basis of Shelley's idealism; it is the vital force in the universe which, he thinks, is able to defeat tyranny and construct a utopia. This love is the source of light that shines with steady luster as an all-embracing devotion to his fellow-men.

\section{The Study}

Romantic era is marked by its concept of sympathy toward natural environment, ideal self-formation and transformation of the society toward an ideal society. The authors of this span are deeply interested in political and scientific changes of the society and have nostalgic view about nature because of the new industrial changes following the Industrial Revolution.

Shelley is considered, by many critics, as the culmination of the Romantic Movement in English literature. He, who thought of himself as a reformer, has witnessed the years following the Industrial Revolution, which changes the peasant society to a nation of manufacturers and brings about materialism. Like other poets of the Romantic Movement, but more than them, Shelley is interested in the political and ideal subjects, but his political emotion goes to a realm beyond any other Romantic poet.

Unlike the first generation of Romantic poets, in Shelley, the absorption in nature is altered to his radical tendency, though he is a good observer of nature. Shelley, as a poet, knows moments of bliss when the beauty of nature absorbs him through the sea of beauty that surrounds him, but he becomes hopeless because this beauty does not go along with the happiness of man. In this way, Shelley's nature poems give us a sense of frustration over human destiny under the dominance of different tyrannies. Thus, he is less meditated than Wordsworth and Coleridge in nature and natural elements and his poetic creativity, revealed in his best lyrics, is combined with the passion for reforming the world to Utopia, a sense that puts him among the world's two or three greatest poets of love and liberty.

Shelley's poetry is a vehicle for his ideal and liberal ideas. He, as one of the most subjective of writers, views all men free and equal. The best pieces of his poetry portray his hope for a better future for man in an ideal world. He believes that every sort of inequality can be eradicated by reformation, and man can reach Utopia and the Golden Age will return. In Shelley's idea, there are different restraints imposed by authority on human thought and society. By removing these obstacles, man can act more beneficially and can make his ideal world. Shelley believes that love can change man's behavior towards one another and towards the universe. Thus, evil will be demolished.

What Shelley presents in his poems, depict a world that should be empty from any sort of tyranny, prejudice, and superstition. In his depicted Utopia he wants no restriction for man; there is no tyranny, no king, no priest, no war and no bound, but his characters, the ideal lovers live in an ideal world in which the dominant power is love.

Although his early poems support a militant republican reform, he found soon that the republican tradition cherishes revenge, so he rejects it in his poetry because in Shelley's view, only love is able to reconstruct a new world. Shelley paces directly from the present to an ideal future. He projects a complete break with the past in the hope of a magnificent future. In Queen Mab he announces that a new day is shortly to dawn, when selfishness will die:

\footnotetext{
A brighter morn awaits the human day,

When every transfer of earth's natural gifts

Shall be a commerce of good words and works;

When poverty and wealth, the thirst of fame,

The fear of infamy, disease and woe,

War with its million horrors, and fierce hell

Shall live but in the memory of time. (251-57)
}

Utopian desire is a persistent theme in Shelley's poetry, as it was a constant drive in his personal life. He, as a revolutionary poet wants to change the world to Utopia. To liberate mankind from the different oppressions through revolution and to bring about a freer and more equal society are what Shelley seeks as a radical poet all his life. All that Shelley wrote depict the tendency and desire to bring about an end to overturn the present system of his society and make it free from the tyranny.

Shelley is not satisfied to imitate the mundane world of ordinary man and his works are mostly at odds with actual life. He, as creative poet is interested in creating a world better than nature and actual world. He is essentially an optimist who believes that good would triumph evil if love dominates man's heart and man's society. His works are in harmony 
with the subjective world of ideals that is more real to him than the world of facts. Thus, Shelley, according to Thurston, presents "the duty of hope" (22) in his poetry, a Utopian desire toward future of man.

Love, in Shelley's poetry, is considered as the "great secret of morals" (Defence 118) and a principal theme that guides man toward morality and immortality. It is a harmonizing element that joins and supports the elements of the universe toward beauty and as he says in Epipsychidion, "Love is like understanding that grows bright, / Gazing on many truths" (162-163). It is the most creative and liberating of all feelings which can reconstitute the world. Shelley considers it as a desire to dissolve all boundaries separating the lover and the beloved, seeking to reunite them and lead them to a better nature. Without love, as Finch declares, "the self remains a prison, and the language which then expresses the self, which gives form to thoughts and feelings, comes also to deform it, limiting its possibilities to those which conform already to tyranny's designs" (30).

Love is the only force in the world that, according to Shelley, is not subject to "Fate, Time, Occasion, Chance and Change" (Prometheus Unbound II. iv, 119-120). It is a creative power when hatred is eradicated from the human mind and human society. Communion with the Eternal reality and beauty is obtained through love, because love is the incarnation of the soul of the world. Love, according to Welburn, "enables man to transform himself and rise above seemingly insurmountable practical and metaphysical obstacles" (159). Love, according to Pottle, "will stream with increasing power to reform the world, not merely the world of mind, but also the world of matter. Human intellect thus empowered will build a new heaven and a new earth" (142-3).

What is real and unchanging is the One Spirit which supports the world with "love and beauty and delight," (Sensitive Plant )and this spirit, "the vision" which, according to Waterlow, "Alastor poet pursued in vain, the Unseen Power of the 'Ode to Intellectual Beauty', is what is always suggested by his poetry at its highest moments" ( ).

Shelley's heroes, too, are ideal characters representing the celestial aspect of man. His Prometheus takes fire and the glory of the gods to man to show man's dignity by making him equal to gods and independent of them. Like Shelley himself, his heroes try to change the world to an ideal world through love and justice and reforming against the tyrannical forces. Although they may fail in obtaining this goal, their failure, according to Thurston, is "preferable to the delusory success of the mass of men, who come to terms with the frustration of life by hardening their hearts to hopeful influences" (26).

Power of poetry and imagination is one of the important themes in Shelley's poetry by which man can get to his ideal world. To Shelley, as Solve believes, "there was a direct connection between life and imagination on the one hand, and imagination and the world of ideal truth on the other. Imagination was the instrument by which the mundane was put in accord with the infinite" (2). Shelley believes that ideal truth can be viewed through imagination which distorts the facts of nature. Thus, Poetry's fundamental role, according to Hendrix, "is to enable human sympathy, and active generosity, or love" (45).

Poetry, based on Shelley's view point in Defence, "acts to produce the moral improvement of man" (487), because it comes "from love and aims for It [love] in order to emanate a fundamental sympathy into everyone and everything that seems other than the observing mind" (Hogle 181). Consequently the release of this power is the foundation of poetry and any revolution.

Shelley has an idealistic view about poetry as a remedy for man's despair in a world full of selfishness and restraint. In Shelley's view "the poets are unacknowledged legislators of the world" (Defense of Poetry); they not only behold present, but also portray future. For Shelley poetry is, as Rogers says, "the highest manifestation of that power known to mankind" (305). His view goes beyond the transient and imperfect world to an ideal world, a Utopia, ruled by beauty and love. The poet, according to Cronin, "removes the veil of familiarity from the world", in order to portray a new and ideal world. Every word of the poets is the expression of a truth which lies behind and beyond it. Fogle believes that "Shelley, indeed, seeks Truth in poetry. But it is a poetic Truth which he pursues, by means of creative imagination" (15). His use of idealism in his poetry creates a higher reality and truth in the mind of the reader, the higher truth that can be seen by Plato's Philosopher-King.

His imagination transforms his radical ideas concerning man and society into visionary poems far from the limitations of time and place. He considers the poet as a visionary and philosopher who is aware of man's future. In Shelley's view, through the imagination of the poet man can live in an ideal world far from ugliness and tyranny. In his Defense of Poetry Shelley writes that the poet "creates anew the universe, after it has been annihilated in our minds by the recurrence of impressions blunted by reiteration" (VII, 137). The chaos of the material world, in Shelley's view, can be moderated by the creative power of imagination.

Shelley wants to free mankind, to purify life of its misery and evil caused by oppression. Throughout his poetic career, he depicts the most beautiful idealism of moral excellence to build a world based on his ideals, with no bondage in 
the way of man's happiness, ruling by love, beauty and justice. Man, in Shelley's view, can triumph every kind of tyranny and oppression by the help of love and ideal good, represented in truth, liberty, wisdom and justice. Hope and love, embodied in Shelley's idealism, can evoke the potent forces. These two powers are the greatest sources in man, the creative power that enables him to reach Utopia, while hatred and despair are the worst agonies in human mind and society.

It is at the last months of his life that Shelley realizes that further rebirth and change is not possible in actual world. Although he is certain about the nobility of his aims, he sees that his efforts are in vain. This is the nostalgic melancholy in Shelley's life in which he depicts his disillusionment in failing to visualize his dreams. This is the time in which he find solace in the other world, the world beyond death in which he can find his Utopia. That is why he says in Adonais, "Life, like a dome of many-coloured glass, / Stains the white radiance of Eternity" (462-3).

\section{Conclusion}

Shelley is one of the most optimistic of the romantic poets. His optimism deepens its own necessity in the face of despair and loss. Optimism and idealism are, according to Shelley, man's weapons with which he stands alone in front of all sorts of temptations of the hostile and indifferent society in order to create a better future for mankind. His revolutionary and humanistic idealism can be seen in the world depicted in his poetry, a world full of love and freedom, a world that is a synthesis of all human values that began to disappear in the nineteenth century. Shelley combines the elements of loss and nostalgia with his ideal vision about future. Shelley's revolutionary idealism is very powerful when he calls his countrymen to a revolution against the absolutistic government while his humanistic idealism is imbued with the vision of the Golden Age in which people are refined by love and freedom. Shelley yearns for an ideal world that can be obtained through the power of love and imagination.

His idealism anticipates the possibility of a different future. He is a poet of the futurist vision, a poet who suffers from the present injustices and has an abstract and ideal vision of the future redress. He offers strong poetic emotions that, he feels, can convert the world, which is now full of slavery, immorality, and hypocrisy, to an ideal world in which every man is his own master, and is spiritually fulfilled by love that is the most powerful weapon against evil and tyranny.

Although he did not achieve the happiness he desired for himself and others, but he was certain about the nobility of his aims and his so-called dreams of freedom stirs our intellect. His poetry takes us away from the real world, restores us to a higher reality, and liberates us from the prison of the actual by giving us spiritual rights in a universe of the mind that is free from the limitations of matter, time and space. His Utopia is a world of innocence not corrupted by ambition and tyranny, a world of beauty and justice in the established order of things, without trouble and without ambition, a world of truth and peaceful life in which man is free.

Shelley's heroes, direct their entire energy to create a utopian world based on the revolutionary ideas of equality and liberty. His poetry conveys to the audience a new method of revolution that will not fall into the paradoxes of a publicprivate binary but happens in the golden land of imagination. Shelley's eternal reality, like Plato's is unchanged and exists beyond time and space. Shelley's ideal world is the combination of all the eternal values of life, values such as truth, beauty, goodness and perfection. A beautiful object in Shelley's poetry is the manifestation of that ideal beauty of the creator. Shelley internalizes the Platonic quest for union with the absolute good. He seeks refuge in this utopia because the real life lacks what the idealist poet pursues.

Shelley desires to reform the world by the power of poetry. He craves to destroy the tyranny and reconstruct a new world of freedom and equality. In almost all of his works, he depicts this Utopian vision of how the world should be and a kind of disillusionment over not attaining this ideal heaven.

\section{Refrences}

Abrams, M. H. (1953). The Mirror and the Lamp: Romantic Theory and the Critical Tradition. New York: Oxford University Press. Allott, Miriam, ed. (1982). Essays on Shelley. Totowa, NJ: Barnes \& Noble.

Baker, Carlos. (1961). Shelley's Major Poetry: The Fabric of a Vision. New York: Russell \& Russell, Inc. Bennett, Andrew. (1999). Romantic Poets and the Culture of Posterity. New York: Cambridge University Press. Bloom, Harold. (1992). Percy Bysshe Shelley: Modern Critical Views. Chelsea: Chelsea House Publishers. Cleckner, Robert F. (1972). Romanticism: Points of View. Englewood Cliffs, NJ: Prentice-Hall, Inc. Cooper, Andrew M. (1988). Doubt and Identity in Romantic Poetry. New Haven: Yale UP.

Cronin, Richard. (2002). Romantic Victorians: English Literature, 1824-1840. Gordonsville: Palgrave Macmillan. Dowden, Edward. (1966). The Life of Percy Bysshe Shelley. London: Routledge and Kegan Paul LTD. Esterhammer, Angela. (2002). Romantic Poetry. Philadelphia: John Benjamins Publishing Company. 
Finch, G. J. (1991). " Larkin, Nature, and Romanticism". Critical Survey 3:1, 53-60.

Fogle, Richard Harter. (1949). The Imagery of Keats and Shelley: A Comparative Study. The United States of America: The University of North Carolina Press.

Hall, Jean. (1980).The Transforming Image: A Study of Shelley's Major Poetry. Urbana: University of Illinois Press.

Hamilton, Paul. (2000). Percy Bysshe Shelley. London: Northcote House Publishers.

Hendrix, Richard. (1978). "The Necessity of Response: How Shelley's Radical Poetry Works." Keats-Shelley Journal 27: 45-69.

Hogle, J. E. (1982). "Shelley's Poetics: The Power As Metaphor." Keats-Shelley Journal 31: 159-97.

Holmes, Richard. (1975). Shelley: The Pursuit. New York: E. P. Dutton and Co.

Hughes, A.M.D. (1963). Shelley: Poems Published in 1820. London: Oxford University Press.

Hutchinson, Thomas. (1952). The Complete Poetical Works of Percy Bysshe Shelley. London: Oxford University Press.

Kingsley, Peter. (1995). Ancient Philosophy Mystery, and Magic: Empedocles and Pythagorean Tradition. Great Britain: Bookcraft Ltd. Milne, Fred L. (1984 Spring). "Shelley's Prometheus Unbound, II.v.10-11." Explicator 42:3, 23-24.

Notopoulos, James A. (1969). The Platonism of Shelley: A Study of Platonism and the Poetic Mind. New York: Noble Offset Printers, INC.

Purinton, Marjean D. (1994). Romantic Ideology Unmasked: the Mentally Constructed Tyrannies in Dramas of William Wordsworth, Lord Byron, Percy Shelley, and Joanna Baillie. Newark: University of Delaware Press.

Reiman, Donald H. and Sharon B. Powers. (1977). Shelley's Poetry and Prose: Authoritative Texts Criticism. New York: W.W. Norton \& Company.

Ridenour, George M., ed. (1965). Shelley: A Collection of Critical Essays. Englewood Cliffs, NJ: Prentice-Hall, Inc.

Rogers, Neville. (1966). Percy Bysshe Shelley: The Esdaile Poems. London: Oxford University Press.

Rovira, James. (2000). An Egoist reading of Shelley's Prometheus Unbound. Drew: Drew University Press.

Solve, Melvin T. (1964). Shelley: His Theory of Poetry. New York: Russell \& Russell, Inc.

Thurston, Norman. (1977). "Duty of Hope". Keats-Shelley Journal 26: 22-29.

Wasserman, Earl R. (1965). Shelley's Prometheus Unbound: A Critical Reading. Baltimore: The John Hopkins Press.

Welburn, Andrew J. (1986). Power and Self-Consciousness in the Poetry of Shelley. New York: St. Martin's Press.

White, Newman Ivey. (1968). Portrait of Shelley. New York: Alfred A. Knope, INC. 